\title{
高齢者消化器癌の外科治療
}

\begin{tabular}{|c|c|c|c|c|c|c|c|c|}
\hline \multicolumn{9}{|c|}{ 東京女子医科大学消化器外科 } \\
\hline 喜多村 & 陽 & 一 & 鈴 木 & 博 & 孝 & 井 & 手 & 博 \\
\hline 木 & & 衛 & 今 & 俊 & 秀 & 吉 & 川 & 達 \\
\hline 高 崎 & & 健 & & & & & & \\
\hline
\end{tabular}

\section{Therapy for Digestive Organs Cancers in the Elderly : Operation Methods}

\author{
Youichi KITAMURA, Hiroyoshi SUZUKI, Hiroko IDE, \\ Mamoru SUZUKI, Toshihide IMAIZUMI, Tatsuya YOSHIKAWA, \\ and Ken TAKASAKI \\ Department of Gastrointestinal Surgery, Tokyo Women's Medical College
}

高齢者消化器癌の外科治療に関して，検討を行った。今回，高齢者群は75歳以上とし，それ未満を対照群とし て検討した。検討期間は過去10年間(1981 1991年) とした。対象症例は食道癌756例で高齢者群は 72 例, 胃癌 2,796

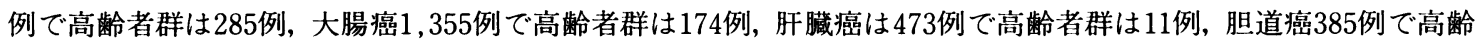
者群は45例, 膵頭部癌は 221 例で高齢者群は21例であった。

検討は各臓器の手術法, 手術侵襲が大きく異なるため臟器別に行った。検討項目は, 術前の併存疾患, 癌進展 の特徵, 術後合併症, 術後生存率などである。各臟器検討の結果, 以下の点が明らかとなった。

1. 食道癌高歯者群は術前呼吸器障害を併存すると, 術後高度の呼吸器合併症を惹起させる率が高い。

2.胃癌高齢者群には对照群と比べて特徵的なことはなにもなかった。

3. 大腸癌高齢者群は術後合併症発生率が高率であり, 特に呼吸器障害の発生率が高かった。

4. 肝癌の高齢者群は対照例に比べHb陽性率が低く, 肝硬変併存例も少ないため, 広範な肝切除が術後合併症 をともなわず可能であった。

5. 膵頭部高齢者群は術後せん妄の発生頻度が高い以外特徵はなかった。

このため, 食道癌の術前呼吸器障害併存例以外は, 高齢を理由に手術術式を考慮する必要は無い。

索引用語：高齢者食道癌 (Esophags cancer in the elderly), 高齢者胃癌 (Gastric cancer in the elderly), 高 㱓者大腸癌 (Colon cancer in the elderly), 高齢者肝癌 (HCC in the elderly), 高齢者膵臓癌 (Pancreas cancer in the elderly)

\section{はじめに}

近年我が国の人口構成は急速に変化し，高齢化 社会となりつつある。それに伴い，患者の高龄化 が医療上各種の問題をもたらしている。消化器外 科の分野でも，本問題をいかに考えたら良いのか 検討する。
消化器癌治療においては, 高秢者の術前生理的 特徵と, 各癌種の加齢による特徵を明確にする必 要がある。また手術侵襲に対する生理的反応の特 徵や, 術後の生活状況をも含んだ経過を把握する ことが, 治療方針を決定する上で必要となる。こ れにより，高齢癌患者は，非高齢癌患者と同等の 手術を行うべきか否かの決定が可能となる。そこ 
Tab. 1 Patients Population

TWMC 1981-1990

\begin{tabular}{lcc} 
site of disease & & ( elderly pts. / total) \\
\hline esophagus & $9.5 \%$ & $(72 / 756$ cases) \\
stomach & 10.2 & $(285 / 2796)$ \\
colon & 12.8 & $(174 / 1355)$ \\
liver & 2.3 & $(11 / 473)$ \\
biliary tract & 11.7 & $(45 / 385)$ \\
pancreas head & 9.5 & $(21 / 221)$
\end{tabular}

Tab. 2 Surgical risk factors in esophageal cancer patients

cardiovascular respiratory liver renal diabetic

$\begin{array}{cccccc}\text { elderly pts. } & 3.9 \% & 19.2 & 1.9 & 1.9 & 7.5 \\ \text { control } & 1.4 & 4.8 & 2.1 & 0.7 & 3.9\end{array}$

で今回消化器病センターにおける過去 10 年間の症 例を对象として各臓器別に検討をおこなった。な お今回は75歳以上を高㱓者として検討した。

\section{対象}

1981 90年までの10年間に行った食道癌756例, 胃癌 2,796 例, 大腸癌 1,355 例, 膵㵴癌 473 例, 胆道 癌385例, 膵頭部癌21例を対象とした。このうち高 歯者は, 食道癌72例, 胃癌285例, 大腸癌174例, 肝臓癌11例, 胆道癌 45 例, 膵頭部癌 21 例であった。

\section{結果}

\section{1. 発生頻度}

各消化器癌別に75歳以上の頻度を検討した。食 道癌は756例 中 72 例 $9.5 \%$, 胃癌 2,796 例 中 285 例 $10.2 \%$, 大腸癌 1,355 例中 174 例 $12.8 \%$, 肝臓癌 472 例中 11 例 $2.3 \%$, 胆道癌 385 例中 45 例 $11.7 \%$, 膵頭 部癌221例中21例 $9.5 \%$ であった（Tab. 1$) 。$

\section{2. 食道癌の検討}

1 ）術前併存疾患：高秢者群 $34.4 \%$, 対照群 $12.9 \%$ であった。高齢者群では, 呼吸器疾患 19.2 \%と高く, 糖尿病7.5\%, 循環器系3.9\%であった。 対照群は, 呼吸器疾患 $4.8 \%$, 糖尿病 $3.9 \%$, 肝疾 患2.1\%であった（Tab.2）。

2 ) 手術術式: 標準術式の右開胸, 縮小手術の 左開胸，姑息手術の非開胸に分けて検討した。右
Tab. 3 Surgical approach of thoracic esophagerl $\begin{array}{lll}\text { right } & \text { left } & \text { no } \\ \text { thoracotomy } & \text { thoracotomy } & \text { thoracotomy }\end{array}$

$\begin{array}{llcr} & & \\ & & & \\ \text { thoracotomy } & \text { thoracotomy } & \text { thoraco } \\ \text { elderly pts. } & 51 \% & 36 & 13 \\ \text { control } & 81 & 14 & 5\end{array}$

Tab. 4 Post-surgical complications in esophageal cancer patients

leakage respiratory cardiovascular renal

$\begin{array}{lllll}\text { elderly pts. } & 24 \% & 28(36) & 4.5 & 6.0 \\ \text { control } & 19 & 14(14) & 2.7 & 1.7\end{array}$

開胸は高齢者群 $51 \%$, 対照群 $81 \%$, 左開胸は高齢 者群 $36 \%$, 対照群 $5 \%$ であった（Tab. 3)。

3 ) 術後合併症: 縫合不全, 肺合併症, 循環器 系合併症, 腎不全につき検討した。肺合併併症は 高齢者群で $28 \%$ あ，このうちの $36 \%$ は術前呼吸 器疾患併存例であった。対照群は $14 \%$ でこのうち $14 \%$ が術前呼吸器疾患併存例であった。縫合不全 は高秢者群で $24 \%$, 对照群で19\%であった。腎不 全は高齢者群 $6 \%$, 对照群1.7\% であった。これら の項目はすべて高齢者群と対照群の間の有意差は 認めなかった（Tab.4）。

4 ) 術後生存率：高齢者群と对照群に分けて術 後生存率を検討すると 3 年, 5 年, 10 年, 生存率 ともに 2 群間に差を認めなかった（Fig. 1)。

\section{3. 胃癌の検討}

1) 術前併存疾患：高齿者群は $48 \%$, 対照群 37 \%の有併存疾患率であった。内訳は, 循環器系で 高齢者群 $26 \%$, 対照群 $20 \%$, 呼吸器系で高齢者群 $9 \%$, 対照群 $5 \%$ と, この 2 項に関して高齢者群 が有意に高率であったが, 肝, 腎, 糖尿病に関し ては 2 群間に差を認めなかった（Tab. 5$) 。$

2 ) 癌進行程度: 癌の壁深達度別, stage別の分 布は高齢者群と対照群の間に有意の差は無かっ た。また同程度の壁深達度に層別化してリンパ節 転移との関係を検討すると, 粘膜癌において, 高 龄者群が対照群よりリンパ節転移が有意差をもっ て高率であった。また同様に脈管侵襲に関して検 討すると, 高㱓者群は脈管侵襲する可能性が対照 群よりが高かった（Tab.6, 7, 8)。 


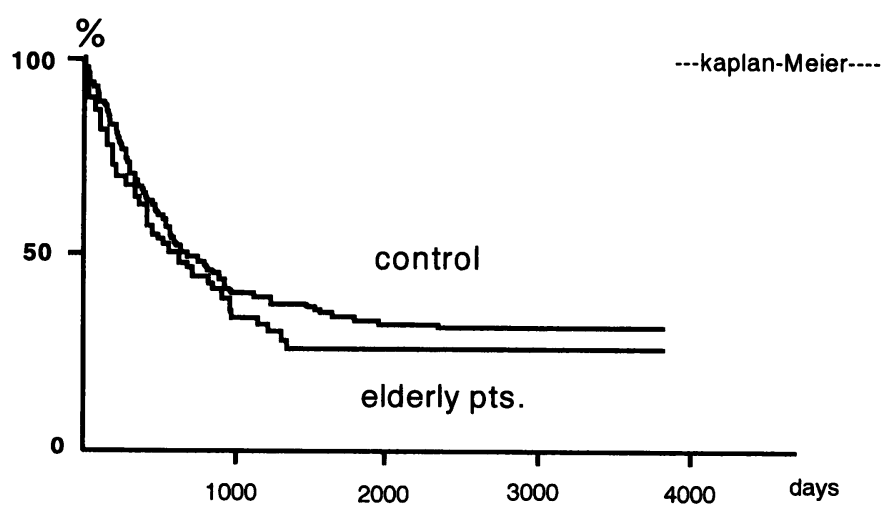

Fig. 1 Post-operative survival curve is esophageal cancer patients

Tab. 5 Surgical risk factors in gastric cancer patients

cardiovascular respiratory liver renal diabetic

$\begin{array}{llllll}\text { elderly pts. } & 26 \% & 9 & 3 & 2 & 8 \\ \text { control } & 20 & 5 & 4 & 1 & 7\end{array}$

Tab. 6 Lymph node dissection of gastric cancer early gastric cancer advanced gastric cancer

\begin{tabular}{lcccc} 
& elderly pts. & control & elderly pts. & control \\
\hline reduced & $38 \%$ & 23 & 38 & 9 \\
standard & 50 & 63 & 40 & 52 \\
extensive & 12 & 14 & 22 & 39
\end{tabular}

Tab. 7 Lymph node metastasis in gastric cancer \begin{tabular}{lllllll}
$\begin{array}{l}\text { Depth of tumor } \\
\text { invasion }\end{array}$ & $m$ & $\mathrm{sm}$ & $\mathrm{mp}$ & $\mathrm{ss}$ & $\mathrm{se}$ & $\mathrm{si}$ \\
\hline
\end{tabular} $\begin{array}{lllllll}\text { elderly pts. } & 9 \% & 27 & 35 & 64 & 82 & 100 \\ \text { control } & 4 & 16 & 40 & 56 & 84 & 92\end{array}$

3 ）術後合併症：術後合併症発生頻度を, 縫合 不全, 呼吸器系, 循環器系, 腎不全, 等につき高 㱓者群と対照群で検討した。呼吸器系の合併症は 高齢者群 $32 \%$, 対照群 $0.9 \%$ と有意差をもって高㱓 者群が高かったが, 他項目では 2 群間に差が無く, 術後出血では対照群が多い傾向にあった。また直 死率は高齿者群 $1.7 \%$, 対照群 $0.8 \%$ と高齢者群が 高頻度であった（Tab. 9$)$ 。

4 ) 術後生存率：胃癌の治癒手術例に関して,
Tab. 8 Ductal invasion in gastric cancer

\begin{tabular}{lllllll}
$\begin{array}{l}\text { Depth of tumor } \\
\text { invasion }\end{array}$ & $\mathrm{m}$ & $\mathrm{sm}$ & $\mathrm{mp}$ & $\mathrm{ss}$ & $\mathrm{se}$ & $\mathrm{si}$ \\
\hline elderly pts. & $2 \%$ & 53 & 66 & 74 & 96 & 100 \\
control & 1 & 40 & 65 & 79 & 91 & 96
\end{tabular}

Tab. 9 Post-surgical complications in gastric cancer patients leakage bleeding respitratory cardiovascular renal

$\begin{array}{llllll}\text { elderly pts. } & 2.8 \% & 0.7 & 3.2 & 0.7 & 0.4 \\ \text { control } & 3.4 & 0.5 & 0.9 & 0.2 & 0.1\end{array}$

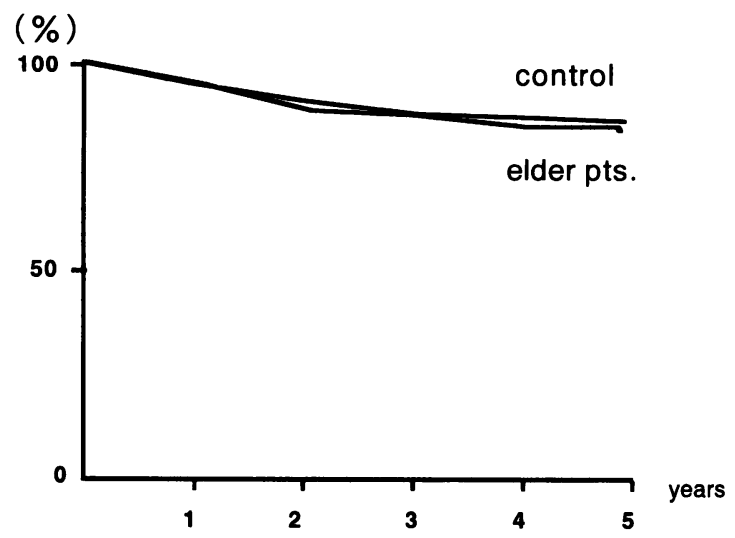

Fig. 2 Survival curve of gastric cancer patients after curative resection

高齿者群と対照群を術後生存率で検討した。 3 年 生存, 5 年生存率ともに 2 群間に差は認められな かった（Fig. 2)。 
Tab. 10 Stage grouping of colon cancer patients Dukes A

Dukes B

Dukes C

\begin{tabular}{llll}
\hline elderly pts. & $21.8 \%$ & 40.4 & 37.8 \\
& & & \\
control & 18.4 & 36.9 & 44.7
\end{tabular}

\section{4. 大腸癌の検討}

1 ）進行程度：大腸癌を最も一般的なDukes分 類で進行程度を分類した。癌が腸管壁内に限局す るAは, 高齢者群 $21.8 \%$, 対照群 $18.4 \%$ であった。 癌が腸管壁を貫いて浸潤するBは高齢者群 40.4 \%, 対照群 $36.9 \%$ であった。そしてリンパ節転移 の有るCは, 高齢者群 $37.8 \%$, 対照群 $44.7 \%$ であっ た (Tab. 10)。

2 ）術前併存疾患：高齢者群では $49.8 \%$ ，対照 群で27.9\%の有併存疾患率であった。内訳は, 循 環器系が高齢者群で $26.4 \%$, 対照群で $20.3 \%$, 呼 吸器系が高齢者群で $8 \%$, 対照群で $4.8 \%$, 脳血管 系が高秢者群で $9.1 \%$, 対照群で1.3\%，と2 群間 で有意差を認めたが，糖尿病，腎疾患については 差を認めなかった。

3 ）手術術式；リンパ節の郭清程度を縮小 (R1)，標準 (R2)，拡大 (R3) に分類して対比し た。高秢者群ではR1，39.5\%，R2，38.9\%，R3， $21.6 \%$, 対照群はR1, 23\%, R2, 38.0\%, R3, 38.8 \%であった。R1とR2との間には有意差を認めた。

4 ) 術後合併症; 合併症発生後頻度は, 高齢者 群 $28.7 \%$, 対照群 $14.0 \%$ で有り両群間に有意群を 認めた。内訳は高齢者群で呼吸器系 $6.8 \%$, 排尿障
Tab. 11 Deaths due to operation in colon cancer patients

\begin{tabular}{lccc} 
& DIC & respiratory & blood poisoning \\
\hline elderly pts. & $0 \%$ & 85.7 & 14.3 \\
control & 11.8 & 23.5 & 5
\end{tabular}

Tab. 12 Post-surgical complications in colon cancer patients

leakage tory \begin{tabular}{ll} 
respira & $\begin{array}{l}\text { cardiova } \\
\text { scular }\end{array}$ renal ileus \\
\hline
\end{tabular}

elderly pts. $\begin{array}{lllll}5.1 \% & 6.8 & 4.1 & 8.0 & 5.7\end{array}$

$\begin{array}{llllll}\text { control } & 5.2 & 1.1 & 3.0 & 0.9 & 4.9\end{array}$

害 $8 \%$, 腸閉塞 $5.7 \%$, 縫合不全 $5.1 \%$ であり, 対 照群で, 呼吸器系 $1.1 \%$, 排尿障害 $0.9 \%$, 腸閉塞 $4.9 \%$, 縫合不全 $5.2 \%$ であった。呼吸器系と, 排 尿障害において 2 群間に有意差を認めた。直死率 は, 高齿者群 $2.3 \%$, 対照群0.8\%であり, 高齢者 群の85\%は肺炎が原因であったが，対照群では肺 炎が原因となったものは $24 \%$ であった（Tab. $11,12)$ 。

5 ) 術後生存率; 治癒切除例を高歯者群と対照 群に分けて 2 群間で術後生存率を対比した。両群 は 3 年生存率でも 5 年生存率でも有意差は認めな かった (Fig. 3)。

\section{5. 肝細胞癌の検討}

1) 併存疾患: HCV 陽性率をみると高龄者群 は $50 \%$ ，対照群は71\%であった。Hb陽性率は高齢 者群は $0 \%$, 対照群は $13 \%$ であった。肝硬変併存
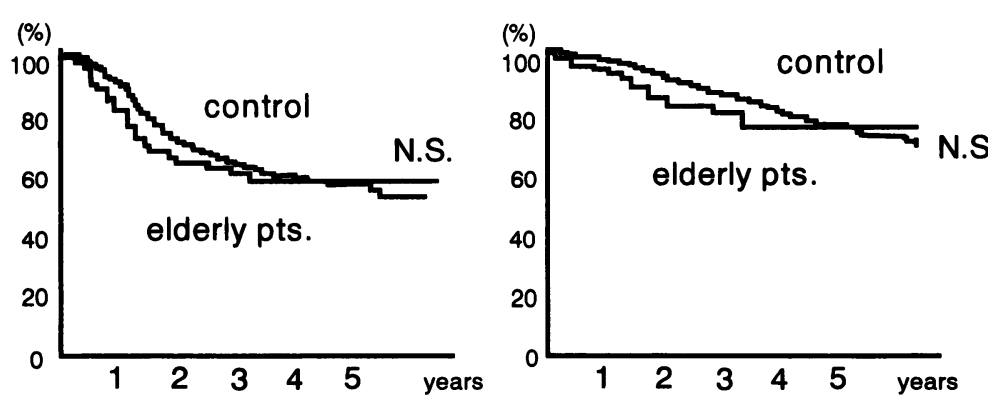

Fig. 3 Post-operative survival curve of colon cancer patients 
Tab. 13 Pre-surgical status of HCC patient

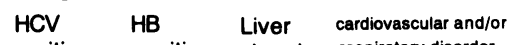

positive positive cirrosis respiratory disorder

$\begin{array}{lcccc}\text { elderly pts. } & 50 \% & 0 & 36 & 57 \\ \text { control } & 71 & 13 & 58 & 43\end{array}$

Tab. 14 Surgical approach for hepatocellular carcinoma (HCC)

\begin{tabular}{cccc} 
& lobectomy & segmentectomy & $\begin{array}{c}\text { partial } \\
\text { resection }\end{array}$ \\
\hline elderly pts. & $48 \%$ & 24 & 28 \\
control & 33 & 31 & 36
\end{tabular}

Tab. 15 Post-surgical complications in HCC patients

\begin{tabular}{lcccc} 
& DWM $^{*}$ & $\begin{array}{l}\text { hepatic } \\
\text { insufficiency }\end{array}$ & abscess & ascites \\
\hline elderly pts. & $0 \%$ & 0 & 17 & 10 \\
control & 4 & 10 & 19 & 22
\end{tabular}

* Death within a month

率は高齢者群は $36 \%$ ，对照群は $58 \%$ であった。ま た一般的疾患の併存率は高齢者群は $57 \%$, 対照群 $43 \%$ であり, 両群とも循環器系, 糖尿病, 呼吸器 系の順であった（Tab. 13）。

2 ) 術式; 肝の切除術を広範囲切除の肝葉切 除,一般的区域切除, 腫瘍のみを取る部分切除に 分けて検討した。高齢者群は, 肝葉切除が $48 \%$, 区域切除 $24 \%$, 部分切除 $28 \%$ であり, 対照群は肝 葉が33\%, 区域切除31\%, 部分切除36\%であった

(Tab. 14)。

3 ) 術後合併症; 合併症発生頻度は高齢者群 29 \%, 対照群 $31 \%$ で有り, 在院死亡は高齢者群には なく, 対照群で $4 \%$ あった。合併症の内訳は, 高 齢者群, 対照群ともに肝切断端の感染が多く, 次 に胸腹水であり，この二項でほぼ $80 \%$ であった。 高齢者群に肝不全は認めず，対照群で $10 \%$ 程度の 頻度であった。在院日数も高齢者群, 対照群に差 はなく平均22日であった（Tab. 15）。

\section{6. 膵頭部癌}

1 ) 術前併存疾患; 有併存疾患率は高齢者群72
Tab. 16 Surgical risk factors in pancreatic cancer patients cardiovascular respiratory renal diabetic

$\begin{array}{llllr}\text { elderly pts. } & 48 \% \text { * } & 10 & 14 & 7.5 \\ \text { control } & 14 * & 10 & 11 & 3.9 \\ & & & \\ & & & \end{array}$

Tab. 17 Stage grouping of pancreatic cancer patients stage I stage II stagellI stage IV

$\begin{array}{lllll}\text { elderly pts. } & 0 \% & 19 & 52 & 29\end{array}$

$\begin{array}{lllll}\text { control } & 3 & 11 & 63 & 23\end{array}$

\%, 対照群 $49 \%$ と二群間に有意差を認めた。内訳 は, 高齿者群で糖尿病 $52 \%$, 心疾患 $48 \%$, 呼吸器 系10\%，腎11\%であった。対照群は糖尿病 $29 \%$, 心疾患 $14 \%$, 呼吸器系 $10 \%$, 腎11\%であった。糖 尿病と心疾患は両群間に有意差を認めた（Tab. 16)。

2 ) 癌進行程度；癌進行程度を 4 段階に分ける と, stage I $0 \%$, stage II $19 \%$, stageIII $52 \%$, stageIV29\%であり対照群は I $3 \%$, II 11\%, III 63 \%, IV23\%であった。両群とstageIII, IVが80\%以 上であり分布に差は認められなかった。進展様式 特徵を検討するため, リンパ節転移, 門脈浸潤, 神経浸潤, 脈管浸潤について高齢者群と対照群の 間で対比したがいずれの項目でも有意差は認めな かった（Tab. 17）。

3 ) 手術術式；標準手術と拡大手術に分けて, 高齢者群と対照群を対比した。両群とも $80 \%$ 以上 の症例で拡大手術が行われており, 差はなかった。

4 ) 術後合併症; 術後合併症は高龄者群で52 \%, 对照群で $36 \%$ に認められた。また手術直接死 亡は高齢者群で $5 \%$, 対照群で $4 \%$ であった。

合併症の内訳は, 糖尿病, 世ん妄, 縫合不全, 肝障害などであるが，せん妄の発生は高齢者群で 有意に多かった（Tab. 18）。

5 ) 術後生存率; 術後生存率を高齢者群と対照 群に分けて検討した。1 年生存率は高齿者群で35 \%, 対照群で $40 \%$ であり， 2 年生存率は高齢者群 
Tab. 18 Post-surgical complications in pancreatic cancer patients

$\begin{array}{lcccccc} & \text { leakage } & \begin{array}{c}\text { hepatic } \\ \text { insufficiency }\end{array} \\ \text { elderly pts. } & 14 \% & 5 & 14 & 19^{*} & 10 \\ \text { control } & 5 & 3 & 10 & 2^{*} & 3 \\ & & & & & & \\ * p<0.01\end{array}$

$0 \%$ あっあだ，対照群との間に有意差はなかっ た (Fig. 4$)$ 。再発形式で見ると, 高齢者群は後腹 膜再発 $88 \%$, 肝転移 $25 \%$ であり，対照群では後腹 膜再発 $49 \%$ ，肝転移 $49 \%$ であった。

\section{考案}

近年高齢者の人口に占める割合が高くなるにつ れ，高齢者を話題とした議論が多くなされるよう になった。医療の分野でも，高齢者の特徴的病態 を研究し，その予防と治療に関する報告が多くお こなわれるようになったきた の外科治療を行っているが, 高齢者の癌を対照群 (非高秢者) と同等に扱ってよいのか。縮小手術 とすべきなのか，または拡大手術とすべきか，い まだ明確な結論を得ていない。また根拠も無く一 般的常識のように高齢者の癌は悪性度が低く，増 殖速度も遅いとする考之が広く信じられ，多くの 併存疾患を持っている事から对照群に比べ縮小手 術を行うべきと考えられてきた2),31。このような考 え方は，はたして正しいのかを検討した。

食道癌; 食道癌患者の術前併存疾患として, 呼 吸器系疾患は高齢者群で $19.2 \%$ であり, 対照群よ
ク有意に高頻度であった。手術術式は高齢者群が 有意に高頻度で呼吸器系に侵襲の少ない術式を選 択してきたが, 術後合併症として呼吸器疾患が対 照群より多かった。特に問題となるのは, 術前呼 吸器併存疾患を有する症例の多くが術後重篤呼吸 器合併症を起こしている点である。また食道癌は 化学療法に高頻度で反応することから ${ }^{3)}$, 術式を 手控えても術後生存率上対照群と差を認めなかっ た。これらの事実を総合すると，高齢者食道癌で 呼吸器併存疾患を有する患者は縮小手術を選択す べきと考えた。

胃癌；胃癌の高齢者と対照群を，同程度の壁深 達度に層別し，リンパ節転移や，脈管侵襲程度を 見た増合高齢者群の方が早い時期よりリンパ管血 管系へ浸潤する事が判明した。すなわち胃癌は高 歯者の方が早期の症例からリンパ節郭清をおこな わなくてはならない4)。また併存疾患は高㱓者群 に多いが，特に問題となる呼吸器の術後合併症は $3 \%$ と少なく重篤なものはなかった5)。胃癌では 高秢者群の術式選択として標準術式か拡大手術を 選ぶべきである。

大腸癌；癌自体の特徵は高㱓者, 对照群の間に 差は認めず，本来両群とも同等の術式を選択すべ きである。しかし合併症の発生率より見て高齢者 群は呼吸器系と排尿障害が問題であった。特に術 後直接死亡の原因として呼吸器系障害の占める割 合が大きく問題であった。また大腸癌手術におい ては，年齢を問わず排尿障害リンパ節郭清の関係 に関する議論がなされてきた。この問題は学会で も意見の別れるところであるが，特に高齢者では

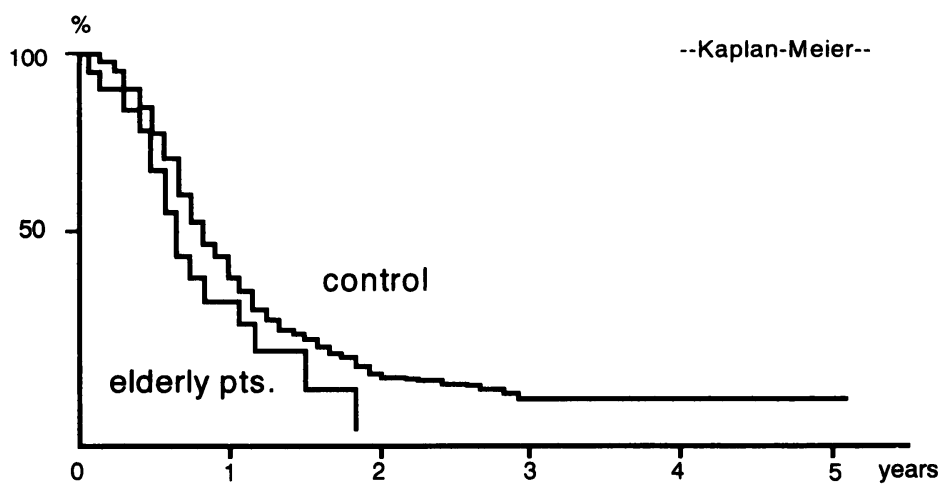

Fig. 4 Post-operative survival curve of pancreatic cancer patients 
十分考慮すべきである ${ }^{6)}$ 。しかし一方, 大腸癌は化 学療法に対する感受性が低い癌である事も考之, 十分なインフォームドコンセント (IC) を行う必 要がある。基本的には, 治癒切除が行われた場合 高齢者群は対照群と同等の良好な術後生存率を得 られる事から，積極的に拡大手術を行うべきであ る。

肝細胞癌; 肝細胞癌手術における最大の関心事 項は肝機能の評価にある。肝機能が不良であれば 切除可能な肝の量も限定される。今回の検討でも 明らかなように, 高齢者肝細胞癌においてはHb感 染やHCV感染率が低く, 肝硬変併存率も少ない。 このため高齢者群では肝葉切除を行う事が多く, また術後の肝不全の発生も少なかった。対照群は $4 \%$ 手術直接死亡を認めたが高㱓者群には認め なかった。これらの事実より見て肝細胞癌は他の 消化器癌と異なり, 高齢者には必要なだけの十分 な肝切除を対照群より安全に施行することが可能 である7)。

膵頭部癌；膵頭部癌は年歯に関係なく高度に進 行してから発見されるのが現状である314)。このた 対照群と同様に拡大手術が必要な症例がほとんど であった。また他の消化器癌と同様に高齢者群は 術前併存疾患保有率が高いことも事実である。し かし術後の合併症は多いが, 手後直接死亡率は対 照群と差を認めなかった 症はせん妄, 膵腸縫合不全, 心肺障害が対照群に 比して多いが, 術後十分な管理を行うことにより 対照群と同様安全に拡大手術が行える。この事よ り高齢者膵頭部癌は積極的に拡大手術を行うべき と考えた。

\section{結 語}

高㱓者消化器癌外科治療につき検討した。高龄 者はやはり多くの併存疾患を持ち, 対照群と同様 の手術を行うと術後合併症の発生頻度は高かっ た。しかし術後合併症は食道癌以外では, 十分な 術後管理により克服する事が可能であった。また 癌自体も高秢者に特徵的なものは無いため対照群 同様積極的な外科治療を行うべきである。

\section{文献}

1）桜井健司, 河野修三：80歳以上高齢者の手術. 臨 外 $44 ： 169-174,1989$

2）宇佐美真, 大柳治文, 斎藤洋一：高㱓者の癌手術. 臨科学 $28 ： 280-291,1992$

3）田中乙夫, 武藤輝一, 佐々木公一他：高齢者食道 癌の外科治療・日消外会誌 $20: 2417-2420,1987$

4）北村正次, 荒井邦圭, 宮下 薰: 高㱓者と若年者 胃癌の臨床病理的特徴及び手術成績の比較検討 · 日消外会誌 $25 ： 756-762,1992$

5）大谷吉秀, 吉野肇一, 户倉康之他：高路者の術後 精神障害とその对策, 消外 $17 ： 1595-1599,1994$

6）森谷宣告, 小山晴夫：高秢者大腸癌手術の特異 性・外科診療 $24: 967-972,1972$

7）出中 明, 小沢和恵, 亥埜恵一他：高㱓者肝癌に 対寸る肝切除成績と周手術期管理 - 外科診療 32 ： 1555-1560, 1990

8）出月康夫, 伊藤 徹：脺頭部十二二指腸切除術 - 外 科診療 $30 ： 639-643,1988$

9）高田忠敬, 内田勝弘：高龄者における胆道癌の特 徵と手術適応, 術後管理. 外科診療 $32: 1561$ 1576, 1990 